\title{
Analysis of Principal Components of the Sea Ice Concentration Fields in the Barents Sea
}

\author{
N.V. Mikhailova, A.V. Yurovsky* \\ Marine Hydrophysical Institute, Russian Academy of Sciences, Sevastopol, Russia \\ *e-mail: a_yurovsky@mail.ru
}

\begin{abstract}
The processes of interaction within the ocean-sea ice-atmosphere system which influence a multiyear ice cover dynamics in the Barents Sea are investigated. Being analyzed, the principal components of the sea ice concentration fields in the Barents Sea make it possible to distinguish three modes of interannual variability of the sea ice concentration. It is shown that the first mode describes $65.4 \%$ of the sea ice concentration total variance and its multiyear trend. The second mode (10.8\%) is related to the variations of the heat inflow due to the sea currents governed by the atmospheric circulation. The third one $(7.8 \%)$ is associated with variability of the total turbulent heat flux from the ocean to the atmosphere at the boundary of the ice edge in the northern Barents Sea.
\end{abstract}

Keywords: Barents Sea, sea ice concentration, inter-annual variability, total turbulent heat flux, currents, wind.

DOI: 10.22449/1573-160X-2017-2-11-18

(C) 2017, N.V. Mikhailova, A.V. Yurovsky

(C) 2017, Physical Oceanography

Introduction. One of the most important regions for monitoring climatic changes in the Western Arctic is the Barents Sea [1, 2] which is attributed to the ice covered ones; but unlike the other Arctic seas, it is never completely covered by ice. Ice formation is usually observed in the north, east (off the archipelago Novaya Zemlya coast) and in the southeast of the sea. Depending on the hydrometeorological conditions, duration of the ice period is $6-10$ months [3]. Global increase of the air temperature observed during the past decades and especially pronounced in the Arctic region ("the effect of polar amplification") has already resulted in rapid reduction of the ice cover. At present, the ice area in the Barents Sea decreases much more rapidly (about $10.5 \%$ during 10 years) than those in the other seas of the Arctic basin that demonstrates the worse negative trend in winter period [4 -6].

Starting from the pilot paper [7], the basic factor conditioning climate of the Western Arctic seas including inter-annual variability of the ice cover area in the Barents Sea [8 - 11] is considered to be heat advection by the North Atlantic Current. On the other hand, many authors emphasize the important role of the atmospheric factors, namely large-scale atmospheric circulation [12, 13], cyclonic activity $[14,15]$, heat fluxes from the ocean to the atmosphere $[16,17]$ and wind, in particular. For example, proceeding from the results of the 465-year numerical experiment, the authors of [18] concluded that the inter-annual variability of the ice area in the Barents Sea is conditioned mainly by the ice import or export occurring due to the local wind forcing; whereas heat transfer by currents is of noticeably less importance. It was also pointed out in [14, 19 and 20] that intensive north or south winds play an important role in displacement of the ice boundary in the Barents Sea. 
The characteristic feature of the Barents Sea ice regime is high inter-annual and seasonal variability of its ice cover [21, 22]. Therefore, the features of the ice processes developing in the sea on various time scales are of undoubted interest. Since the most significant changes are observed in winter, the aim of the investigation is to study both the inter-annual variability of the Barents Sea ice cover area in winter (December - February) and the factors conditioning it.

Initial data and the methods of research. The following data were used in the paper: monthly average values of ice concentration in the Barents Sea (1978 2016) obtained based on the passive microwave sounding data from the National Snow and Ice Data Center, USA (NSIDC) and represented on the uniform $(25 \times 25 \mathrm{~km})$ grid (http://nsidc.org/data/nsidc-0002.html); monthly average values of the surface air temperature, the atmospheric pressure on the sea level, the zonal and meridional components of the wind speed, the turbulent flows of apparent and latent heat obtained from the NASA MERRA reanalysis array (1979 - 2016) and represented on the grid with the spatial resolution $0.5 \times 0.67^{\circ}$.

To distinguish the modes of the sea ice concentration inter-annual variability, the standard method of principal components was applied. The further study was carried out using the correlation-regression method.

Results and discussion. The regime of long-term variability of the sea ice concentration (Sea Ice Concentration - SIC) permits to distinguish three modes; the first one describes $65.4 \%$ of the SIC variability, the second $-10.8 \%$ and the third - $7.8 \%$. Spatial structure of the modes $\left(P C_{1}, P C_{2}, P C_{3}\right)$ and the corresponding temporal expansion coefficients $\left(K_{1}, K_{2}, K_{3}\right)$ are shown in Fig. 1.

The spatial structure of the first mode (Fig. 1, $a$ ) is identical to the spatial distribution of the SIC linear trend coefficient (Fig. 2). Hence, the dominant contribution to the SIC inter-annual variability in winter in the Barents Sea is done by the trend. It is negative practically on the whole water area, i.e. the ice concentration and area gradually reduce. The region of the maximum values of the first principal component located along $77^{\circ} \mathrm{N}$ in the east of the Barents Sea, corresponds to that of the most intensive ice cover shrinking (on the average, the ice concentration decrease is $21 \%$ during 10 years).

The oscillations with the period $\sim 5$ years are observed in the time variation of the expansion coefficient $K_{1}$ corresponding to the first mode (Fig. $1, b$ ).

The correlation analysis has shown that the surface air temperature $\left(T_{a}\right)$ and the wind speed meridional component $(V)$ constitute the basic factors governing SIC in the given region. The correlation coefficient between the sea ice concentration averaged over the area $76-78^{\circ} \mathrm{N}, 42-62^{\circ} \mathrm{E}$ and $T_{a}$ was $R=-0.94$; between SIC and the wind speed meridional component $-R=-0.65$, and between SIC and the total turbulent heat flux $(Q)-R=-0.67$. Close relation is also revealed between the time coefficient $K_{1}$ and $V$, the corresponding correlation coefficient $R=-0.64$. The relations with the atmospheric pressure on the sea level and the wind speed zonal component $(U)$ are absent. 

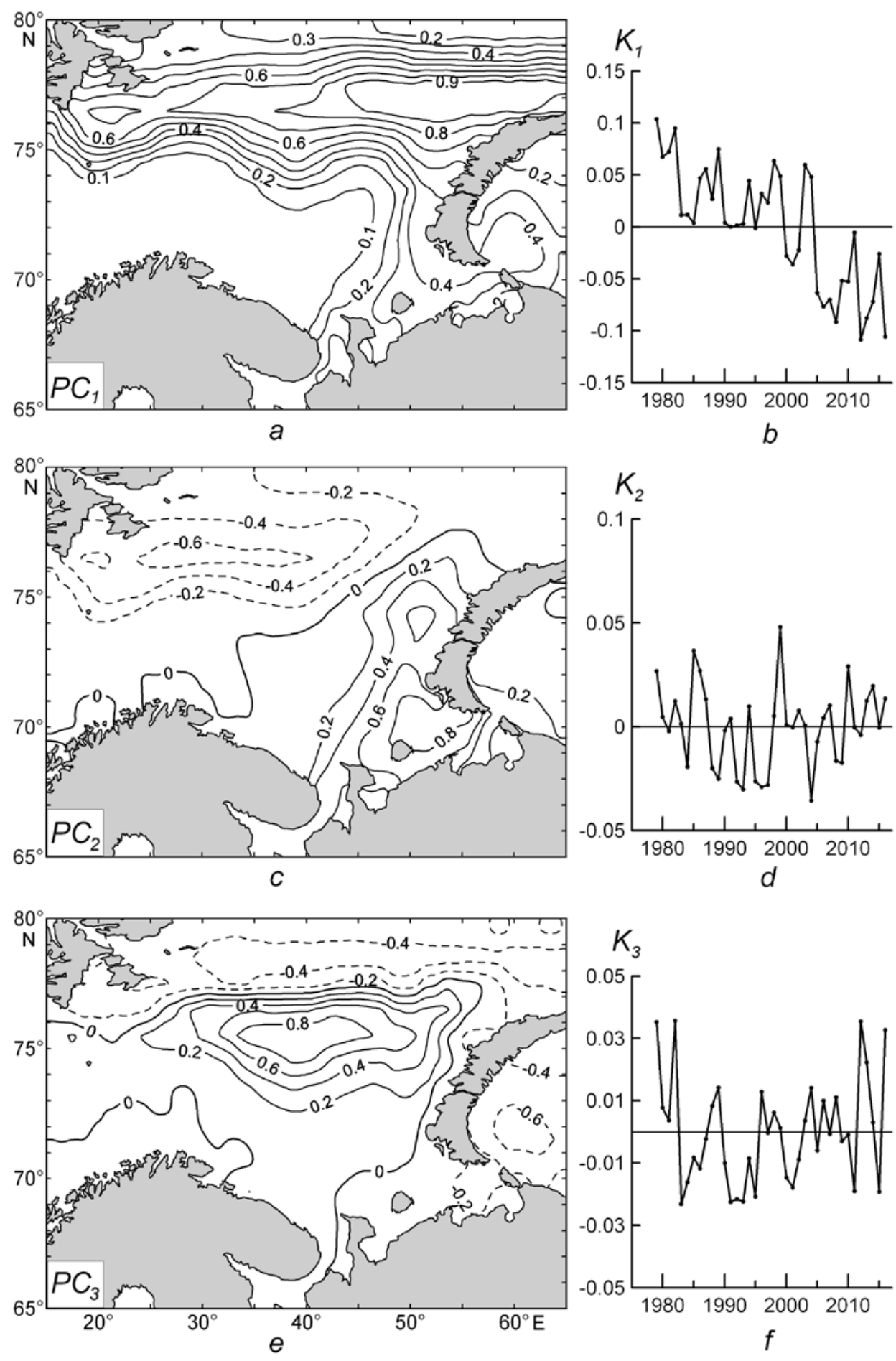

Fig. 1. Spatial structure of the first three modes of the sea ice concentration field in the Barents Sea for December - February, 1978 - 2016 and the corresponding temporal expansion/resolution coefficients

PHYSICAL OCEANOGRAPHY NO. 2 (2017) 


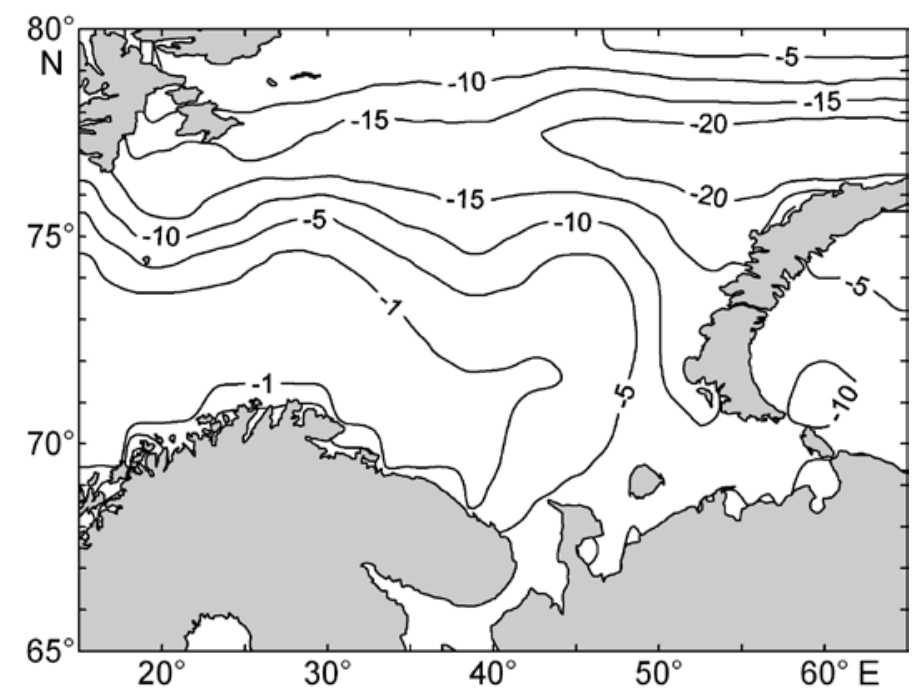

Fig. 2. Coefficient of the sea ice concentration linear trend $\left(\times 10^{-3}\right)$ in the Barents Sea for $1978-2016$

Great bulk of ice (95 - $97 \%$ ) in the Barents Sea represents a drift-ice [3] which moves being forced by the wind and sea currents or pressed by the neighboring ice fields. It follows from Fig. 3, that the north wind (negative values of $V$ ) promotes increase of SIC due to the ice export from the interior Arctic and the heightened inflow of cold Arctic water from the region between the island Spitzbergen and the archipelago Franz Josef Land. Low water temperatures and heat deficiency contribute to the ice formation processes and are accompanied by the SIC positive anomalies. Note that at the beginning of the analyzed period, the north winds alternated with the south ones, but since 2005 the situation changed and the south winds became predominant in this region of the Barents Sea. It seems to be conditioned by the changes in the large-scale atmospheric circulation.

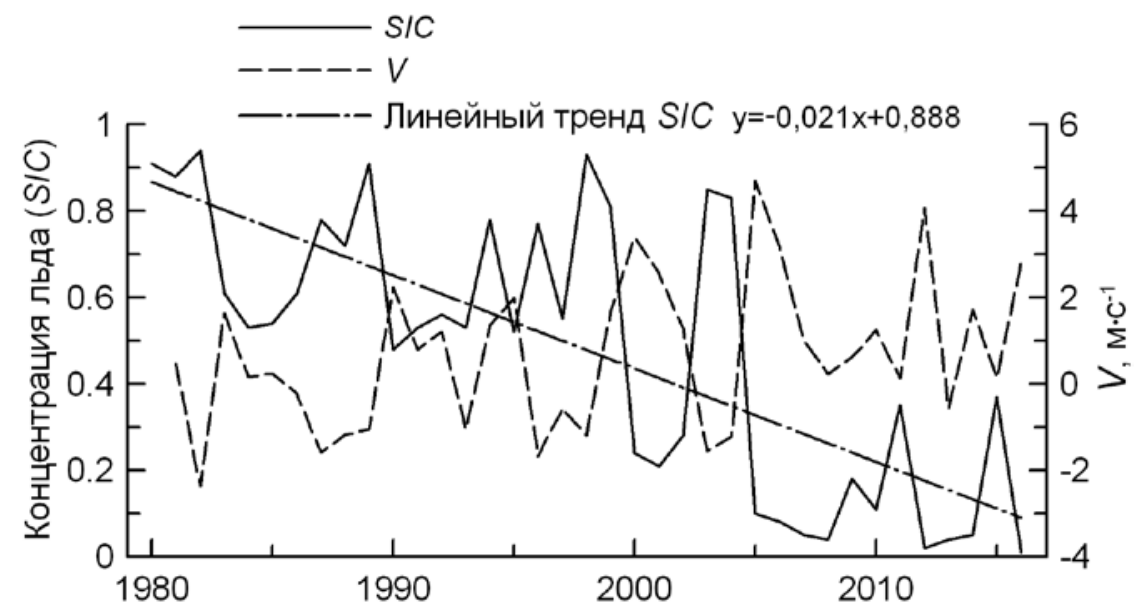

Fig. 3. Multi-year variation of the sea ice concentration and the wind speed meridional component averaged over the area $76-78^{\circ} \mathrm{N}$ and $42-62^{\circ} \mathrm{E}$ 
The second mode (Fig. 1, c) describes, probably, synchronous change of heat advection due to the currents in the southeast and northwest of the Barents Sea. In the region of the second mode positive center $\left(69-71^{\circ} \mathrm{N}\right.$ and $\left.48-54^{\circ} \mathrm{E}\right)$, the Kolguevo-Pechora current which is a continuation of the warm Murmansk current, collides with the cold Litke current flowing out from the Kara Sea. Being forced by the atmospheric circulation and wind, the currents can intensify, thus affecting the temperature regime of the sea in this region. In the northeast of the Barents Sea, the cold currents propagating to the south off the archipelago Franz Josef Land and along the coast of the island Spitzbergen are reinforced due to filling up with the water inflow from the Arctic basin. Increase or decrease of the currents' velocity in the southeastern part of the Barents Sea (usually it takes place when the atmospheric cyclones pass over it) leads to acceleration or deceleration of the whole sea currents' system that forms a cyclonic gyre [3].

The correlation analysis showed that the surface air temperature and the wind speed zonal component are the basic factors governing SIC in the southeast and northwest of the Barents Sea. The correlation coefficient between the sea ice concentration averaged over the region $69-71^{\circ} \mathrm{N}$ and $48-54^{\circ} \mathrm{E}$, and $T_{a}$ was $R=-0.92$; the one between SIC and the wind speed zonal component $-R=-0.61$; and between SIC and the total turbulent heat flux $-R=-0.59$. There is no relation with the atmospheric pressure on the sea level and the wind speed meridional component. Moderate relation is revealed between the time coefficient $K_{2}$ and $U$, the corresponding $R$ is -0.58 . Note that the time variation of the expansion coefficient $K_{2}$ for the second mode (Fig. 1, $d$ ) is also accompanied by periodicity (the oscillation period is about three years).

Consequently, at the west wind, the warm currents' velocity increases (the Murmansk and the Kolguevo-Pechora currents) and the heat inflow to the southwestern part of the Barents Sea increases, that promotes formation of the SIC negative anomalies, growth of the air and the sea surface layer temperatures, and slowing down of ice formation. And vice versa, at the eastern winds, the cold water outflow from the Kara Sea southwestern part increases that leads to the ice drift and inflow to the Barents Sea through the Novaya Zemlya straits. Therefore, ice concentration in the Barents Sea increases (Fig. 4).

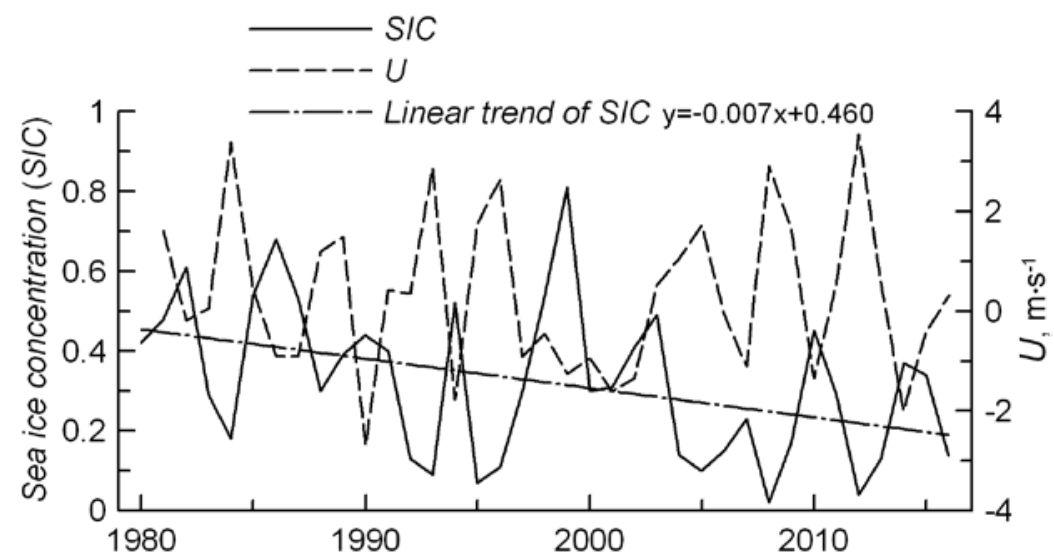

Fig. 4. Multi-year variations of the sea ice concentration and the wind speed zonal component averaged over the region $69-71^{\circ} \mathrm{N}$ and $48-54^{\circ} \mathrm{E}$

PHYSICAL OCEANOGRAPHY NO. 2 (2017) 
The region of the strongest variability of the ice edge boundary in the northern Barents Sea in winter [23] corresponds to the main positive center of the third mode $\left(74-76^{\circ} \mathrm{N}\right.$ and $35-45^{\circ} \mathrm{E}$ ) (Figure $\left.1, \mathrm{~d}\right)$. The ice edge position is one of the most important characteristics of the ice conditions in marine environment. Its displacement affects redistribution of heat and momentum fluxes between the ocean and the atmosphere. If ice substantially blocks the turbulent heat flux from the ocean to the atmosphere, the ocean heat losses over the open water areas increase by an order that subsequently results in modification of water and air masses on different time scales, and influences the sea ice thermodynamics in the edge zone. Besides, in high latitudes in cold season, the so-called cold invasions are often observed in the ice edge area, in other words, when very cold Arctic air masses move to the relatively warm sea surface. In these cases, the energy exchange between the ocean and the atmosphere is particularly intensive: the instantaneous total turbulent heat flux can achieve $500-1000 \mathrm{~W} / \mathrm{m}^{2}$. Therefore, the authors consider the third mode as describing the change of heat fluxes from the ocean to the atmosphere when the ice cover boundary is shifted.

In the region $74-76^{\circ} \mathrm{N}$ and $35-45^{\circ} \mathrm{E}$, the closest relation is observed between SIC and $Q:-R=-0.58$ (Fig. 5). The relations with the other atmospheric parameters are less pronounced: the correlation coefficient between SIC and $T_{a}$ is $R$ $=-0.50$; the one between SIC and $V-R=-0.38$. The atmospheric pressure at the sea level and the wins speed zonal component exert no significant influence upon the $S I C$ variability in this region. In the time variation of the expansion coefficient $K_{3}$ for the third mode, evident periodicity is absent (Fig. 1, e).

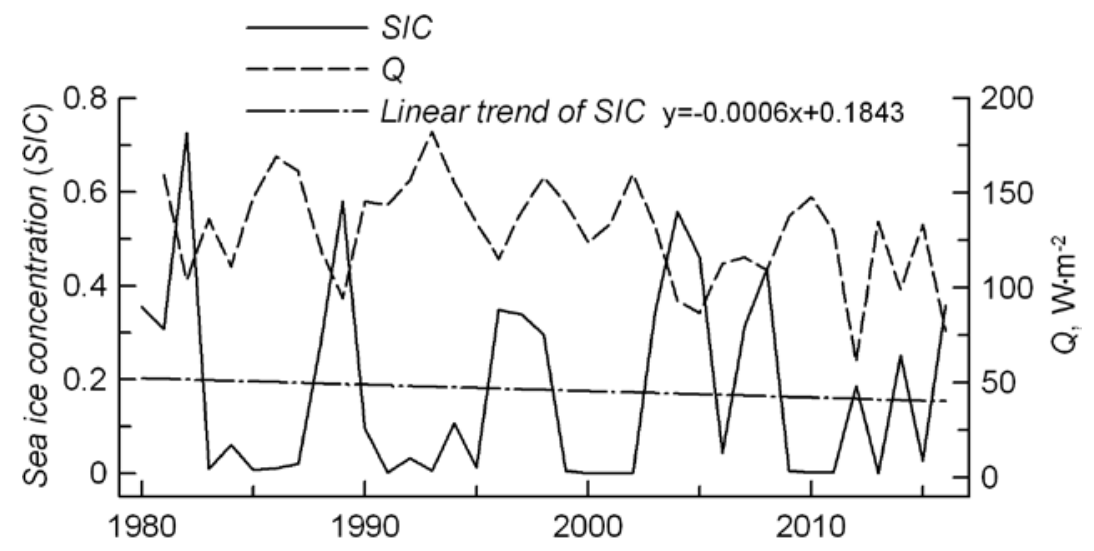

Fig. 5. Multi-year variation of the sea ice concentration and the total turbulent heat flux averaged over the region $74-76^{\circ} \mathrm{N}$ and $35-45^{\circ} \mathrm{E}$

Conclusion. Studies of the long-term variability of the sea ice concentration in the Barents Sea have shown that during the past three decades a significant decrease of ice cover was observed, especially in the sea northeastern part. On the average, the ice concentration here decreases by $21 \%$ in course of 10 years.

Analysis of the main components of the sea ice concentration field allowed us to distinguish three stable modes which describe $84 \%$ of the sea ice concentration dispersion. Each mode is connected with the interaction processes in the ocean-sea 
ice-atmosphere system which condition the spatial-temporal structure of ice concentration in the Barents Sea.

The work is carried out within the framework of the state task on the theme № 0827-2015-0001 "Fundamental research of the processes in the oceanatmosphere-lithosphere system which condition spatial-temporal variability of environment, and global and regional climate" (code "Climate").

\section{REFERENCES}

1. Matishov, G.G., Dzhenyuk, S.L., Zhichkin, A.P. and Moiseev, D.V., 2010. Klimaticheskie Izmeneniya Morskikh Ekosistem Evropeiskoy Arktiki [Climatic Changes of the European Arctic Marine Ecosystems]. Problemy Arktiki i Antarktiki, [e-journal] 3(86), pp. 7-21. Available at: http://www.aari.ru/misc/publicat/paa.php?ls=\&count=36\&pagenum=4 [Accessed 10 October 2016] (in Russian).

2. $\quad$ Smedsrud, L.H., Esau, I., Ingvaldsen, R.B., Eldevik, T., Haugan, P.M., Li, C., Lien, V.S., Olsen, A., Omar, A.M., Otterå, O.H., Risebrobakken, B., Sandø, A.B., Semenov, V.A. and Sorokina, S.A., 2013. The Role of the Barents Sea in the Arctic Climate System. Rev. Geophys., [e-journal] 51, pp. 415-449. doi:10.1002/rog.20017

3. Girdyuk, G.V., Dzhenyuk, S.L., Zykova, G.G. and Terziev, F.S. eds., 1990. Gidrometeorologiya i Gidrokhimiya Morey SSSR. T.1, Barentsevo More, Vyp. 1, Gidrometeorologicheskie Usloviya [Hydrometeorology and Hydrochemistry of the Seas in the USSR, 1, the Barents Sea, vol. 1, Hydrometeorological Conditions]. L.: Gidrometeoizdat, 280 p. Available at: URL: http://www.geokniga.org/books/10838 [Accessed 15 October 2016] (in Russian).

4. Screen, J.A. and Simmonds, I., 2010. The Central Role of Diminishing Sea Ice in Recent Arctic Temperature Amplification. Nature, [e-journal] 464, pp. 1334-1337. doi:10.1038/nature09051

5. Kern, S., Kaleschke, L. and Spreen, G., 2010. Climatology of the Nordic (Irminger, Greenland, Barents, Kara and White/Pechora) Seas Ice Cover Based on 85 GHz Satellite Microwave Radiometry: 1992-2008. Tellus A, [e-journal] 62 (4), pp. 411-434. Available at: http://onlinelibrary.wiley.com/doi/10.1111/j.1600-0870.2010.00457.x/pdf [Accessed 12 October 2016]

6. Cavalieri, D.J. and Parkinson, C.L., 2012. Arctic Sea Ice Variability and Trends, 1979-2010. Cryosph., [e-journal] 6 (4), pp. 881-889. doi:10.519/tc-6-871-2012

7. Helland-Hansen, B. and Nansen, F., 1909. The Norwegian Sea - Its Physical Oceanography Based upon the Norwegian Researches 1900-1904. Report on Norwegian Fishery and Marine-Investigations. Kristiania: Det Mallingske Bogtrykkeri. Vol. II. No. 2, 422 p. Available at: https://brage.bibsys.no/xmlui/handle/11250/114874?show=full [Accessed 12 October 2016].

8. Polyakov, I.V., Beszczynska, A., Carmack, E.C., Dmitrenko, I.A., Fahrbach, E., Frolov, I.E., Gerdes, R., Hansen, E., Holfort, J., Ivanov, V.V., Johnson, M.A., Karcher, M., Kauker, F., Morison, J., Orvik, K.A., Schauer, U., Simmons, H.L., Skagseth, Ø., Sokolov, V.T., Steele, M., Timokhov, L.A., Walsh, D. and Walsh, J.E., 2005. One More Step Toward a Warmer Arctic. Geophys. Res. Lett., [e-journal] 32, L17605. doi:10.1029/2005GL023740

9. Polyakov, I.V., Timokhov, L.A., Alexeev, V.A., Bacon, S., Dmitrenko, I.A., Fortier, L., Frolov, I.E., Gascard, J.-C., Hansen, E., Ivanov, V.V., Laxon, S., Mauritzen, C., Perovich, D., Shimada, K., Simmons, H.L., Sokolov, V.T., Steele, M. and Toole, J., 2010. Arctic Ocean Warming Contributes to Reduced Polar Ice Cap. J. Phys. Oceanogr., [e-journal] 40 (12), pp. 2743-2756. https://doi.org/10.1175/2010JPO4339.1

10. Årthun, M., Eldevik, T., Smedsrud, L.H., Skagseth, Ø. and Ingvaldsen R.B., 2012. Quantifying the Influence of Atlantic Heat on Barents Sea Ice Variability and Retreat. J. Clim., [e-journal] 25(13), pp. 4736-4743. https://doi.org/10.1175/JCLI-D-11-00466.1 
11. Yashayaev, I. and Seidov, D., 2015. The Role of the Atlantic Water in Multidecadal Ocean Variability in the Nordic and Barents Seas. Progr. Oceanogr., [e-journal] 132, pp. 68-127. doi:10.1016/j.pocean.2014.11.009

12. Zhang, X., Sorteberg, A., Zhang, J., Gerdes, R. and Comiso, J.C., 2008. Recent Radical Shifts of Atmospheric Circulations and Rapid Changes in Arctic Climate System. Geophys. Res. Lett., [e-journal] 35(22), L22701. doi:10.1029/2008GL035607

13. Zhichkin, A.P., 2015. Peculiarities of Interannual and Seasonal Variations of the Barents Sea Ice Coverage Anomalies. Russian Meteorology and Hydrology, [e-journal] 40(5), pp. 319-326. doi:10.3103/S1068373915050052

14. Sorteberg, A. and Kvingedal, B., 2006. Atmospheric Forcing on the Barents Sea Winter Ice Extent. J. Clim., [e-journal] 19 (19), pp. 4772-4787. https://doi.org/10.1175/JCLI3885.1

15. Simmonds, I. and Keay, K., 2009. Extraordinary September Arctic Sea Ice Reductions and Their Relationships with Storm Behavior over 1979-2008. Geophys. Res. Lett., [e-journal] 36(19), L19715. doi:10.1029/2009GL039810

16. Selivanova, J.V., Tilinina, N.D., Gulev, S.K. and Dobrolubov, S.A., 2016. Impact of Ice Cover in the Arctic on Ocean-Atmosphere Turbulent Heat Fluxes. Oceanology, [e-journal] 56(1), pp.14-18. doi:10.1134/S0001437016010185

17. Sorokina, S.A., Li, C., Wettstein, J.J. and Kvamstø, N.G., 2016. Observed Atmospheric Coupling between Barents Sea Ice and the Warm-Arctic Cold-Siberian Anomaly Pattern. J. Clim., [e-journal] 29, pp. 495-511. https://doi.org/10.1175/JCLI-D-15-0046.1

18. Koenigk, T., Mikolajewicz, U, Jungclaus, J.H. and Kroll, A., 2009. Sea Ice in the Barents Sea: Seasonal to Interannual Variability and Climate Feedbacks in a Global Coupled Model. Clim. Dyn., [e-journal] 32(7), pp. 1119-1138. doi:10.1007/s00382-008-0450-2

19. Pavlova, O., Pavlov, V. and Gerland, S., 2014. The Impact of Winds and Sea Surface Temperatures on the Barents Sea Ice Extent, a Statistical Approach. J. Mar. Syst., [e-journal] 130, pp. 248-255. doi:10.1016/j.jmarsys.2013.02.011

20. Herbaut, C., Houssais, M.-N., Close, S. and Blaizot, A.-C., 2015. Two Wind-Driven Modes of Winter Sea Ice Variability in the Barents Sea. Deep-Sea Res. I, [e-journal] 106, pp. 97-115. http://doi.org/10.1016/j.dsr.2015.10.005

21. Frolov, I.E., Gudkovich, Z.M., Karklin, V.P., Kovalev, Ye.G. and Smolyanitsky, V.M., 2007. Klimaticheskie Izmeneniya Ledodykh Usloviy v arkticheskikh Moryakh Evraziyskogo Shelfa [Climatic Changes of Ice Conditions in the Arctic Seas of the Euroasian Shelf]. Problemy Arktiki i Antarktiki, [e-journal] 1(75), pp. 149-160. Available at: http://www.aari.ru/misc/publicat/paa.php?ls=\&count=36\&pagenum=7 [Accessed 9 October 2016].

22. Inoue, J., Hori, M.E. and Takaya, K., 2012. The Role of Barents Sea Ice in the Wintertime Cyclone Track and Emergence of a Warm-Arctic Cold-Siberian Anomaly. J. Clim., [ejournal] 25(7), pp. 2561-2568. doi:10.1175/JCLI-D-11-00449.1

23. Boitsov, V.D., 2007. Sezonnaya izmenchivost' polozheniya kromki l’dov Barentseva morya [Seasonal variability of the ice edge location in the Barents Sea]. In: A.P. Alekseev, V.N. Kochikov and V.V. Maslennikov, eds. 2007. Voprosy promyslovoy okeanologii. Moscow: VNIRO Publ. Vol. 4, No. 2, pp. 206 - 220. Available at: http://dspace.vniro.ru/handle/123456789/2241?show=full [Accessed 10 September 2016]. 